\title{
EUROPEAN HUB FOR INVADERS: RISK ASSESSMENT OF FRESHWATER AQUARIUM FISHES EXPORTED FROM THE CZECH REPUBLIC
}

\author{
Lukáš KALOUS*, Jiří PATOKA, and Oldřich KOPECKÝ \\ Department of Zoology and Fisheries, Faculty of Agrobiology, Food and Natural Resources, \\ Czech University of Life Sciences Prague, Czech Republic
}

Kalous L., Patoka J., Kopecký O. 2015. European hub for invaders: Risk assessment of freshwater aquarium fishes exported from the Czech Republic. Acta Ichthyol. Piscat. 45 (3) 239-245.

Background. The aquarium fish trade is characterized by an enormous number of species. Aquarium fish may have an impact on native biota by means of their invasiveness as well as through pathogen transfer. The Czech Republic has become a gateway for aquatic pets into the European Union. The aims of this study were to identify the most common aquarium fish species on the wholesale market, to estimate temperature suitability for seasonal (winter and summer) survival in the EU, and also to assess the invasiveness risk of the most common aquarium fishes with the strongest temperature matching.

Materials and methods. Data on aquarium fish species, their origin, and availability from producers and traders based in the Czech Republic were collected based on all available sources. The target area was defined as all member states of the EU. Estimation of the temperature suitability for each species was done using Climatch 1.0 software. The Freshwater Fish Invasiveness Screening Kit (FISK) was employed for species with temperature suitability within the target area exceeding $10 \%$ in the coldest quarter of the year.

Results. In total, 1118 fish species representing 51 families were identified. Thirty-three species belonging to 13 families were classified as "very common". Three sources of origin were identified: domestic production within the EU, farm production outside the EU, and wild harvests in the region of origin. The major suppliers outside the EU are in south-east Asia. Only one common species originated from wild harvests. FISK scoring divided the 11 species evaluated as having the strongest temperature suitability in the EU (TSEU) into seven species bearing medium risk and four species representing high risk. The family Cyprinidae was the most frequently represented among all evaluated taxa (seven species), but the majority of high-risk fishes belonged to the family Poeciliidae (three species). The highest score was earned by Carassius auratus (Linnaeus, 1758).

Conclusion. The risk potential of aquarium fishes most traded in the EU seems to be not alarming. Attention should be focused on the possibility of novel pathogen transfer to native aquatic biota as an important aspect of regulating the aquarium fish trade.

Keywords: introduction pathway, aquarium trade, invasive species, freshwater fish, risk assessment, FISK

\section{INTRODUCTION}

Aquaculture, recreational fisheries, and trade in aquatic pets are considered the main driving forces behind the introduction of non-native aquatic species (Copp et al. 2005a). The aquarium fish trade in particular involves an enormous number of species, of which ca. 5300 and ca. 1800 are of freshwater and marine origin, respectively (Hensen et al. 2010, Rhyne et. 2012). Approximately 90\% of freshwater aquarium fishes originate from aquaculture production (Tlusty 2002) and breeding in captivity is steadily growing, especially in Asia (Jayalal and Ramachandran 2012, Raghavan et al. 2013).

In contrast to the immense diversity of fishes and locations of their native ranges, the international trade is charac- terized by just several re-exporting hubs that encompass the majority of the world's aquarium fish supply (Livengood and Chapman 2007, Jayalal and Ramachandran 2012). By far the most important hub is Singapore, which covers about $30 \%$ of the total trade (Jayalal and Ramachandran 2012, Rani et al. 2014). The Czech Republic, in addition to its own production, has become a gateway to the European Union (EU) (Livengood and Chapman 2007, Jayalal and Ramachandran 2012, Maceda-Veiga et al. 2013) and constitutes an important hub for imports into the largest markets for aquatic pets (Livengood and Chapman 2007).

Although the majority of freshwater aquarium fishes in Europe are kept within indoor closed systems, some are released into the wild - usually by hobbyists (Copp 
et al. 2007, Patoka et al. 2014b). Released animals may sometimes form viable populations (Elvira and Almodóvar 2001, Koščo et al. 2010, Papavlasopoulou et al. 2013).

Potential invasiveness for the EU has already been assessed for freshwater turtles used as pets (Kopecký et al. 2013, Masin et al. 2014) and crayfish (Chucholl 2013, Papavlasopoulou et al. 2014, Patoka et al. 2014a), but the risk from freshwater aquarium fish has been evaluated only from local perspectives (Copp et al. 2005b, 2005c, Papavlasopoulou et al. 2013, Simonović et al. 2013). Although there is an intuitive assumption that the majority of released fish cannot survive winter in a large part of the EU, the presence of non-native species in the natural environment for only a short period may still affect native biota and aquaculture through such means as pathogen transfer (Peeler et al. 2011). Imported aquarium fishes could be infected by viruses (Vesely et al. 2011), antibiotic-resistant bacteria (Dobiasova et al. 2014, Gerzova et al. 2014), or parasites (Kennedy 1993, Boeger et al. 2002, Sobecka et al. 2012), some of which may have zoonotic potential (Weir et al. 2012, Mehrdana et al. 2014).

Eradication of invaders, diseases, and parasites in aquatic ecosystems is usually very difficult and costly. It is easier to prevent a new introduction than subsequently try to mitigate its environmental impacts (Copp et al. 2005a, Maceda-Veiga et al. 2013). Obviously, early identification of potential invaders, their origins, and the reasons for their possible introductions is crucial for proper environmental management (Kolar and Lodge 2001). The commercial aquarium fish trade sector is directly connected to potential release into the wild of non-native fishes. This is because the distribution channel ends with live fish, which are sold to customers in pet shops (Duggan 2010).

We focused our data collection on wholesale trading within an EU trade hub, because later tracking of fish is very problematic or nearly impossible. The aims of the present work were to identify the most common aquarium fish species on the wholesale market in the Czech Republic, to estimate temperature suitability to survive on EU territory in winter and summer for the most common aquarium fish, and to assess the invasiveness risk of the most common aquarium fish with the strongest temperature matching.

\section{MATERIALS AND METHODS}

Identification of the most common aquarium fish species. Over the period of June 2013 to May 2014, we composed a list of aquarium fish species and collected data on their origin and availability from producers and traders based in the Czech Republic. Data were obtained from the offers of five major wholesalers and 93 private producers of aquarium fishes who sell their production abroad. Based on personal consultations and/or physical inspections, we eliminated numerous misnomers and alternative market names from the preliminary summary list. We used the Catalog of Fishes (Eschmeyer 2014) to validate scientific names. Availability on the market was evaluated according to Chucholl (2013).
Target area. The EU states were assumed as the target area, including the autonomous islands of Macaronesia (namely the Azores, Madeira, and the Canary Islands) in a manner similar to Kopecký et al. (2013). Due to their geographical remoteness, other overseas departments and regions were not included into our study as parts of the EU. Estimation of temperature suitability within the target area. We examined the temperature match between source area and target area for very common aquarium fish. We computed climate match data (Bomford 2008) in Climatch 1.0 (Bureau of Rural Sciences) by source region versus target region for each species. Besides the whole year (used for FISK only) we compared the warmest, and the coldest quarter of the year. Where the model predicted a relatively close climate match between the source area and the meteorological station in the target area according to the temperature variable (score $\geq 7.0$ ), this was interpreted as meaning that temperature is not a constraint for the species survival (Britton et al. 2010). We calculated the temperature suitability in the EU (further referred to as TSEU) for each species as the percentage of meteorological stations with Climatch score $\geq 7.0$ within the target area. Additionally, a paired $t$-test in R statistical software (R Development Core Team 2014) was employed to reveal differences between the warmest and coldest periods of the year for all analysed species of fish.

Assessment of invasiveness risk. To evaluate potential invasiveness, we employed the Freshwater Fish Invasiveness Screening Kit (FISK) (Copp et al. 2005b, Copp et al. 2009, Lawson et al. 2013) on species with TSEU exceeding $10 \%$ in the coldest quarter of the year. We used the $10 \%$ threshold of TSEU as demonstrative criterion based on qualified estimate of the obtained data for FISK. Information regarding the biology, ecology, biogeography, exploitation by humans, invasive history, and presence of 'undesirable traits' of each evaluated species were obtained through a review of the scientific literature (Nelson 2006, Froese and Pauly 2014).

\section{RESULTS}

In total, we credibly identified 1118 fish species representing 51 families in the EU aquarium fish trade. Thirty-three species belonging to 13 families were assessed as 'very common' due to their availability in large quantities through the entire season.

Traded aquarium fishes had three sources of origin:

- Domestic production within the EU;

- Farm production outside the EU; and

- Wild harvests in region of origin (Table 1).

The major suppliers outside the EU were located in South and south-east Asia (China, India, Indonesia, Malaysia, Singapore, Taiwan, Thailand, and Vietnam), South America (Brazil, Colombia, and Peru), Africa (Congo and Nigeria), and the Middle East (Israel). Only a single, very common species, Chromobotia macracanthus (Bleeker, 1852), endemic to Borneo and Sumatra (Indonesia), originated exclusively from wild harvest. 
Table 1

List of the most traded ornamental fish species

\begin{tabular}{|c|c|c|c|c|c|c|}
\hline \multirow{2}{*}{ Species } & \multirow{2}{*}{ Family } & \multirow{2}{*}{$\begin{array}{l}\text { Main } \\
\text { origin }\end{array}$} & \multicolumn{2}{|c|}{ TSEU } & \multicolumn{2}{|c|}{ FISK } \\
\hline & & & Winter & Summer & Score & Category \\
\hline Carassius auratus (Linnaeus, 1758) & Cyprinidae & $\mathrm{D}, \mathrm{O}$ & 95 & 73 & 26 & high \\
\hline Corydoras paleatus (Jenyns, 1842) & Callichthyidae & $\mathrm{D}$ & 38 & 38 & 4 & medium \\
\hline Poecilia latipinna (Lesueur, 1821) & Poeciliidae & $\mathrm{D}, \mathrm{O}$ & 35 & 29 & 22 & high \\
\hline Tanichthys albonubes Lin, 1932 & Cyprinidae & $\mathrm{D}, \mathrm{O}$ & 29 & 39 & 5.5 & medium \\
\hline Clarias batrachus (Linnaeus, 1758) & Clariidae & $\mathrm{O}$ & 24 & 99 & 16.5 & medium \\
\hline Poecilia sphenops Valenciennes, 1846 & Poeciliidae & $\mathrm{D}, \mathrm{O}$ & 20 & 98 & 20 & high \\
\hline Trichopodus leerii (Bleeker, 1852) & Osphronemidae & $\mathrm{D}$ & 17 & 83 & 12 & medium \\
\hline Trigonostigma heteromorpha (Duncker, 1904) & Cyprinidae & $\mathrm{D}$ & 16 & 91 & 1 & medium \\
\hline Xiphophorus helleri Heckel, 1848 & Poeciliidae & $\mathrm{D}$ & 15 & 78 & 21 & high \\
\hline Trichogaster lalius (Hamilton, 1822) & Osphronemidae & $\mathrm{O}$ & 14 & 93 & 13 & medium \\
\hline Danio rerio (Hamilton, 1822) & Cyprinidae & $\mathrm{D}, \mathrm{O}$ & 14 & 93 & 4.5 & medium \\
\hline Thorichthys meeki Brind, 1918 & Cichlidae & $\mathrm{D}$ & 9 & 33 & & \\
\hline Astronotus ocellatus (Agassiz, 1831) & Cichlidae & $\mathrm{D}, \mathrm{O}$ & 8 & 15 & & \\
\hline Xiphophorus maculatus (Günther, 1866) & Poeciliidae & $\mathrm{D}, \mathrm{O}$ & 4 & 25 & & \\
\hline Gymnocorymbus ternetzi (Boulenger, 1895) & Characidae & $\mathrm{D}$ & 3 & 20 & & \\
\hline Trichopodus trichopterus (Pallas, 1770) & Osphronemidae & $\mathrm{D}$ & 2 & 51 & & \\
\hline Paracheirodon innesi (Myers, 1936) & Characidae & $\mathrm{D}, \mathrm{O}$ & 2 & 30 & & \\
\hline Pangasianodon hypophthalmus (Sauvage, 1878) & Pangasiidae & $\mathrm{O}$ & 2 & 24 & & \\
\hline Epalzeorhynchos frenatum (Fowler, 1934) & Cyprinidae & $\mathrm{O}$ & 2 & 23 & & \\
\hline Pangio kuhlii (Valenciennes, 1846) & Cobitidae & $\mathrm{O}$ & 1 & 51 & & \\
\hline Balantiocheilos melanopterus (Bleeker, 1850) & Cyprinidae & $\mathrm{O}$ & 1 & 49 & & \\
\hline Puntius tetrazona (Bleeker, 1855) & Cyprinidae & $\mathrm{D}$ & 1 & 49 & & \\
\hline Megalechis thoracata (Valenciennes, 1840) & Callichthyidae & $\mathrm{D}$ & 1 & 33 & & \\
\hline Ancistrus dolichopterus Kner, 1854 & Loricariidae & $\mathrm{D}$ & 1 & 30 & & \\
\hline Piaractus brachypomus (Cuvier, 1818) & Characidae & $\mathrm{O}$ & 1 & 30 & & \\
\hline Paracheirodon axelrodi (Schultz, 1956) & Characidae & $\mathrm{D}$ & 1 & 28 & & \\
\hline Gyrinocheilus aymonieri (Tirant, 1883) & Gyrinocheilidae & $\mathrm{O}$ & 1 & 15 & & \\
\hline Chromobotia macracanthus (Bleeker, 1852) & Botiidae & $\mathrm{F}$ & 0 & 31 & & \\
\hline Poecilia reticulata Peters, 1859 & Poeciliidae & $\mathrm{D}, \mathrm{O}$ & 0 & 30 & & \\
\hline Mikrogeophagus ramirezi (Myers et Harry, 1948) & Cichlidae & $\mathrm{D}$ & 0 & 27 & & \\
\hline Pterophyllum scalare (Schultze, 1823) & Cichlidae & $\mathrm{D}$ & 0 & 27 & & \\
\hline Synodontis nigriventris David, 1936 & Mochokidae & $\mathrm{D}, \mathrm{O}$ & 0 & 24 & & \\
\hline Betta splendens Regan, 1910 & Osphronemidae & $\mathrm{O}$ & 0 & 3 & & \\
\hline
\end{tabular}

$\mathrm{D}=$ domestic production in $\mathrm{EU}, \mathrm{O}=$ farm production outside $\mathrm{EU}, \mathrm{F}=$ wild harvest in region of origin; TSEU = temperature suitability in the EU [\%], FISK = Freshwater Fish Invasiveness Screening Kit; The dashed line separates the fish with more than $10 \%$ TSEU.

\section{Evaluation of temperature suitability with target area. DISCUSSION}

When comparing all 33 fishes classified as very common, the warmest period of the year in the target area showed a stronger climate match with the source area (paired $t$-test, $t$ $=6.98, P<0.0001)$. The particular temperature suitability for each species in the warmest and coldest periods of the year within the target area is given in Table 1 .

Assessment of invasiveness risk. FISK scoring divided the 11 species evaluated with the highest TSEU in winter (over $10 \%$ ) into seven species representing medium risk for the EU and four species bearing high risk (Table 1). Fishes of the family Cyprinidae occurred most frequently among all evaluated taxa (seven species), but the majority of high-risk fishes belonged to the family Poeciliidae (three species).

Of all the evaluated fishes, the highest risk score was obtained by Carassius auratus (Linnaeus, 1758) from family Cyprinidae, commonly known as goldfish.
In total, we identified 1118 traded freshwater aquarium fish species, a number which is slightly higher than that published by Livengood and Chapman (2007), who recognized 1100 species. Our findings emphasize the importance of the Czech Republic as a distribution hub for the aquarium fish trade. Although not all of the fish are continuously present in the Czech Republic, they can be imported upon customer request and redistributed to other European countries.

Gozlan et al. (2010) has suggested that the survival and spread of the majority of aquarium fishes is unlikely throughout the EU due to their ecological and physiological requirements, as they mostly come from tropical or subtropical climates. This was undoubtedly proven by the test of 33 fish species classified as very common on the market. Only 13 species displayed TSEU exceeding 10\%. 
Within the territory of the EU, such locations are apparently situated in southern European countries. Only one species, Carassius auratus (family Cyprinidae), which is tolerant to cold water (Rixon et al. 2005, Kottelat and Freyhof 2007), had TSEU of at least $95 \%$ in winter. Traded varieties of goldfish clearly form a genetically monophyletic lineage (Rylková et al. 2010), therefore we analysed C. auratus sensu stricto separately from other representatives of the C. auratus complex (sensu Takada et al. 2010). The area of lower Yangtze River in China, which is considered as the only source of $C$. auratus for domestication (Rylková et al. 2010, Wang et al. 2013) was used for comparison of climate conditions between the target area (EU) and the region of origin. In contrast van der Veer and Nentwig (2014) in their evaluation used Carassius auratus and Carassius gibelio (Bloch, 1782) together.

Although the probability of freshwater aquarium fishes being established within the EU is relatively low, their survival during summer is likely (Elvira and Almodóvar 2001, Ellis 2006). Our results show that during the warmest period of the year, aquarium fish are not very much affected by temperature over most of the territory of the EU (Table 1). Twenty-six species out of 33 evaluated showed TSEU of at least $25 \%$ in summer, and 8 species had summer TSEU of at least $70 \%$. This may be conducive to short-term survival in natural habitats where aquarium fishes are released by hobby keepers. This finding supports concerns as to possible transfer of novel pathogens into the native fish assemblage through uncontrolled release of infected aquarium fish. This is most likely to happen in areas of high human population density, where higher propagule pressure could be expected (Copp et al. 2005b, Kalous et al. 2013). Go and Whittington (2006) already presented that ornamental gouramis from Southeast Asia are the source of megalocytivirus (Family Iridoviridae) causing losses on native Maccullochella peelii (Mitchell, 1838) in Australia.

Human-mediated introduction of pathogens into new areas is recognized as one of the most important factors driving disease emergence in wildlife populations (Daszak et al. 2001). Not much attention has been devoted to possible disease and/or parasite transfer from introduced aquarium fish to local native fishes in Europe even though the problem has already been noted by Peeler et al. (2011).

The presented list of 33 aquarium fish species could be used as a starting point for examining the pathogen control process.

The risk assessment is meaningful only for species with considerable propagule pressure and which may survive winter in the target area. Duggan et al. 2006 proved the existence of the relations between frequency of occurrence of aquarium fishes in shops and likelihood of their introduction and establishment. We therefore evaluated 11 of the most traded aquarium fish species having TSEU of at least $10 \%$. The fishes evaluated as medium risk are: South American catfish, Corydoras paleatus (Jenyns, 1842), with the second highest TSEU, reaching 38\% in winter, but so far with no records in the wild; south Asian catfish, Clarias batrachus (Linnaeus, 1758), with TSEU reaching 24\%, already found in England but only in chan- nels sustained by the heated waters from a power station or dead due to temperature intolerance (Zięba et al. 2010); as well as three cyprinids: Danio rerio (Hamilton, 1822); Tanichthys albonubes Lin, 1932; and Trigonostigma heteromorpha (Duncker, 1904); and two gouramis: Trichogaster lalius (Hamilton, 1822) and Trichopodus leerii (Bleeker, 1852), with TSEU exceeding 10\%.

The highest FISK score among the most common aquarium fishes was obtained by Carassius auratus. The evaluation of this fish by FISK as high risk is in accordance with observed reproduction of the species in open waters, e.g., in England and the Iberian Peninsula (Copp et al. 2005c, Ribeiro et al. 2008). Three high-risk species belonged to the family Poeciliidae. Poecilia latipinna (Lesueur, 1821) has already been introduced and established in Greece (Papavlasopoulou et al. 2013). In contrast, Poecilia sphenops Valenciennes, 1846 has been established only in thermal water springs in Hungary and Romania (Petrescu-Mag et al. 2008), which could reflect its higher temperature demands (see Table 1). The same seems to apply for Xiphophorus helleri Heckel, 1848 , which is occasionally recorded in Slovakia but is probably not established there (Májsky 2000, Koščo et al. 2010). Interestingly, Poecilia reticulata Peters, 1859, which was introduced and established in some regions of Spain (Elvira and Almodóvar 2001), was evaluated by our model as having $0 \%$ TSEU, probably pointing to some weaknesses in our approach. While we compared the air temperatures of source and target areas, these do not completely reflect water temperatures (Britton et al. 2010). In addition, the temperature suitability of particular species might not be completely explained by the minimum and maximum air temperatures of the region of origin (Tojo et al. 2010). In any case, several prediction models, including FISK, are based on the same climate data (Bomford 2008, Henderson et al. 2011).

It might be advisable to test also the climate data of regions where fish have been introduced and established, but this approach discriminates against species that have not yet been established outside of their regions of origin or in places which do not correspond to their minimum or maximum temperature suitability. Unfortunately, the scientific literature also lacks information regarding the minimum survival temperature for the majority of aquarium fishes as either adults or larvae. Such information could play an important role in any risk assessment model.

The aforementioned weaknesses notwithstanding, this is the first comprehensive assessment of potential risks of aquarium fish species within the territory of the EU. More detailed studies are needed to evaluate risks within specific areas, where more precise data on water temperature and propagule pressure are available. Although the risk potential of the most traded fishes in the EU seems to be not alarming, attention should nevertheless be directed to the possibility of novel pathogen transfer to native aquatic biota as an important aspect of regulating the aquarium fish trade. 


\section{ACKNOWLEDGMENTS}

We are grateful to Romana Palečková and Daniela Daňková for their valuable help with data collection. This study was supported by the Technology Agency of the Czech Republic (TD010045) and CIGA project No. 20152007. The English was corrected by a native-speaking editor from English Editorial Services, s.r.o., Brno, Czech Republic.

\section{REFERENCES}

Boeger W.A., Piasecki W., Sobecka E. 2002. Neotropical Monogenoidea. 44. Mymarothecium viatorum sp. n. (Ancyrocephalinae) from the gills of Piaractus brachypomus (Serrasalmidae, Teleostei) captured in a warm-water canal of a power plant in Szczecin, Poland. Acta Ichthyologica et Piscatoria 32 (2): 157-161.

Bomford M. 2008. Risk assessment models for establishment of exotic vertebrates in Australia and New Zealand. Invasive Animals Cooperative Research Centre, Canberra, Australia.

Britton J., Cucherousset J., Davies G., Godard M., Copp G. 2010. Non-native fishes and climate change: Predicting species responses to warming temperatures in a temperate region. Freshwater Biology 55 (5): 1130-1141.

DOI: $10.1111 / \mathrm{j} .1365-2427.2010 .02396 . x$

Chucholl C. 2013. Invaders for sale: Trade and determinants of introduction of ornamental freshwater crayfish. Biological Invasions 15 (1): 125-141.

DOI: $10.1007 / \mathrm{s} 10530-012-0273-2$

Copp G.H., Bianco P.G., Bogutskaya N.G., Erős T., Falka I., Ferreira M.T., Fox M.G., Freyhof J., Gozlan R.E., Grabowska J., Kovac V., Moreno-Amich R., Naseka A.M., Penaz M., Povz M., Przybylski M., Robillard M., Russell I.C., stakenas S., Sumer S., Vila-Gispert A., Wiesner C. 2005a. To be, or not to be, a non-native freshwater fish? Journal of Applied Ichthyology 21 (4): 242-262.

DOI: $10.1111 / \mathrm{j} .1439-0426.2005 .00690 . \mathrm{x}$

Copp G.H., Garthwaite R., Gozlan R.E. 2005b. Risk identification and assessment of non-native freshwater fishes: A summary of concepts and perspectives on protocols for the UK. Journal of Applied Ichthyology 21 (4): 371.

DOI: $10.1111 / \mathrm{j} .1439-0426.2005 .00692 . \mathrm{x}$

Copp G.H., Templeton M., Gozlan R.E. 2007. Propagule pressure and the invasion risks of non-native freshwater fishes: A case study in England. Journal of Fish Biology 71 (Suppl. D): 148-159. DOI: $10.1111 / \mathrm{j} .1095-8649.2007 .01680 . \mathrm{x}$

Copp G.H., Vilizzi L., Mumford J., Fenwick G.V., Godard M.J., Gozlan R.E. 2009. Calibration of FISK, an invasiveness screening tool for nonnative freshwater fishes. Risk Analysis 29 (3): 457-467. DOI: $10.1111 / \mathrm{j} .1539-6924.2008 .01159 . x$

Copp G.H., Wesley K.J., Vilizzi L. 2005c. Pathways of ornamental and aquarium fish introductions into urban ponds of Epping Forest (London, England): The human vector. Journal of Applied Ichthyology 21 (4): 263-274.

DOI: $10.1111 / \mathrm{j} .1439-0426.2005 .00673 . \mathrm{x}$

Daszak P., Cunningham A.A., Hyatt A.D. 2001. Anthropogenic environmental change and the emergence of infectious diseases in wildlife. Acta Tropica 78 (2): 103-116. DOI: $10.1016 / \mathrm{S} 0001-706 \mathrm{X}(00) 00179-0$

Dobiasova H., Kutilova I., Piackova V., Vesely T., Cizek A., Dolejska M. 2014. Ornamental fish as a source of plasmid-mediated quinolone resistance genes and antibiotic resistance plasmids. Veterinary Microbiology 171 (3-4): 413-421.

DOI: $10.1016 /$ j.vetmic. 2014.02 .011

Duggan I.C. 2010. The freshwater aquarium trade as a vector for incidental invertebrate fauna. Biological Invasions 12 (11): 3757-3770.

DOI: 10.1007/s10530-010-9768-X

Duggan I.C., Rixon C.A.M., Macisaac H.J. 2006. Popularity and propagule pressure: Determinants of introduction and establishment of aquarium fish. Biological Invasions 8 (2): 377-382.

DOI: $10.1007 / \mathrm{s} 10530-004-2310-2$

Ellis J. 2006. Occurrence of exotic fishes in East Anglian waters: porcupinefish Diodon hystrix and piranha Pygocentrus sp. Transactions of the Suffolk Naturalist Society 42 39-42.

Elvira B., Almodóvar A. 2001. Freshwater fish introductions in Spain: Facts and figures at the beginning of the 21 st century. Journal of Fish Biology 59 (Suppl. A): 323-331. DOI: $10.1111 / \mathrm{j} .1095-8649.2001 . t b 01393 . \mathrm{x}$

Eschmeyer W. (ed.) 2014. Catalog of fishes. [Updated: 05 October 2014.] California Academy of Science, San Francisco, http://research.calacademy.org/research/ Ichthyology/Catalog/fishcatmain.asp. [Accessed: May 2014.]

Froese R., Pauly D. (eds.) 2015. FishBase. [version 01/2015] http://www.fishbase.org

Gerzova L., Videnska P., Faldynova M., Sedlar K., Provaznik I., Cizek A., Rychlik I. 2014. Characterization of microbiota composition and presence of selected antibiotic resistance genes in carriage water of ornamental fish. PLoS One 9 (8): e103865.

DOI: 10.1371 journal.pone.0103865

Go J., Whittington R. 2006. Experimental transmission and virulence of a megalocytivirus (Family Iridoviridae) of dwarf gourami (Colisa lalia) from Asia in Murray cod (Maccullochella peelii peelii) in Australia. Aquaculture 258 (1-4): 140-149.

DOI: $10.1016 /$ j.aquaculture.2006.04.033

Gozlan R.E., Britton J.R., Cowx I., Copp G.H. 2010. Current knowledge on non-native freshwater fish introductions. Journal of Fish Biology 76 (4): 751-786. DOI: $10.1111 / \mathrm{j} .1095-8649.2010 .02566 . x$

Henderson W., Bomford M., Cassey P. 2011. Managing the risk of exotic vertebrate incursions in Australia. Wildlife Research 38 (6): 501-508. DOI: 10.1071/WR11089 
Hensen R.R., Ploeg A., Fosså S.A. 2010. Standard names for freshwater fishes in the Ornamental Aquatic Industry. OFI educational publication 5. Ornamental Fish International, Maarssen, the Netherlands.

Jayalal L., Ramachandran A. 2012. Export trend of Indian ornamental fish industry. Agriculture and Biology Journal of North America 3 (11): 439-451. DOI: $10.5251 /$ abjna.2012.3.11.439.451

Kalous L., Petrtýl M., Patoka J., Rylková K. 2013. Fishes in the campus of the Czech University of Life Sciences Prague. Pp. 199-203. In: Workshop on Biodiversity, Jevany, Czech Republic. Vol. 5. DOI: $10.13140 / 2.1 .2392 .9282$

Kennedy C. 1993. Introductions, spread and colonization of new localities by fish helminth and crustacean parasites in the British Isles: A perspective and appraisal. Journal of Fish Biology 43 (2): 287-301. DOI: $10.1111 /$ j.1095-8649.1993.tb00429.x

Kolar C.S., Lodge D.M. 2001. Progress in invasion biology: Predicting invaders. Trends in Ecology and Evolution 16 (4): 199-204.

DOI: $10.1016 / \mathrm{s} 0169-5347(01) 02101-2$

Kopecký O., Kalous L., Patoka J. 2013. Establishment risk from pet-trade freshwater turtles in the European Union. Knowledge and Management of Aquatic Ecosystems 410, 02 .

DOI: $10.1051 / \mathrm{kmae} / 2013057$

Koščo J., Košuthová L., Košuth P., Pekárik L. 2010. Non-native fish species in Slovak waters: Origins and present status. Biologia 65 (6): 1057-1063. DOI: $10.2478 / \mathrm{s} 11756-010-0114-7$

Kottelat M., Freyhof J. 2007. Handbook of European freshwater fishes. Kottelat and Freyhof, Cornol, Switzerland, Berlin, Germany.

Lawson L.L., Hill J.E., Vilizzi L., Hardin S., Copp G.H. 2013. Revisions of the Fish Invasiveness Screening Kit (FISK) for its application in warmer climatic zones, with particular reference to peninsular Florida. Risk Analysis 33 (8): 1414-1431. DOI: $10.1111 / \mathrm{j} .1539-6924.2012 .01896 . x$

Livengood E., Chapman F. 2007. The ornamental fish trade: An introduction with perspectives for responsible aquarium fish ownership. University of Florida IFAS Extension FA124 1-8.

Maceda-Veiga A., Escribano-Alacid J., de Sostoa A., García-Berthou E. 2013. The aquarium trade as a potential source of fish introductions in southwestern Europe. Biological Invasions 15 (12): 2707-2716.

DOI: $10.1007 / \mathrm{s} 10530-013-0485-0$

Májsky J. 2000. Ichtyofauna termálnych vôd Podunajskej nížiny a Hornonitrianskej kotliny. [Ichthyofauna of thermal waters of the Podunajská lowland and the Hornonitrianska basin.] Ochrana prírody (Banská Bystrica) 18 155-160. [In Slovak.]

Masin S., Bonardi A., Padoa-Schioppa E., Bottoni L., Ficetola G.F. 2014. Risk of invasion by frequently traded freshwater turtles. Biological Invasions 16 (1): 217-231. DOI: $10.1007 / \mathrm{s} 10530-013-0515-\mathrm{y}$
Mehrdana F., Jensen H.M., Kania P.W., Buchmann K. 2014. Import of exotic and zoonotic trematodes (Heterophyidae: Centrocestus sp.) in Xiphophorus maculatus: Implications for ornamental fish import control in Europe. Acta Parasitologica 59 (2): 276-283. DOI: $10.2478 / \mathrm{s} 11686-014-0237-\mathrm{z}$

Nelson J.S. 2006. Fishes of the world. 4th edn. John Wiley and Sons, New York NY, USA.

Papavlasopoulou I., Perdikaris C., Vardakas L., Paschos I. 2014. Enemy at the gates: Introduction potential of non-indigenous freshwater crayfish in Greece via the aquarium trade. Central European Journal of Biology 9 (1): 1-8.

DOI: $10.2478 / \mathrm{s} 11535-013-0120-6$

Papavlasopoulou I., Vardakas L., Perdikaris C., Kommatas D., Paschos I. 2013. Ornamental fish in pet stores in Greece: A threat to biodiversity? Mediterranean Marine Science 15 (1): 126-134.

DOI: $10.12681 / \mathrm{mms} .484$

Patoka J., Kalous L., Kopecký O. 2014a. Risk assessment of the crayfish pet trade based on data from the Czech Republic. Biological Invasions 16 (12): 2489 2494.

DOI: $10.1007 / \mathrm{s} 10530-014-0682-5$

Patoka J., Petrtýl M., Kalous L. 2014b. Garden ponds as potential introduction pathway of ornamental crayfish. Knowledge and Management of Aquatic Ecosystems 414, 13.

DOI: $10.1051 / \mathrm{kmae} / 2014019$

Peeler E.J., Oidtmann B.C., Midtlyng P.J., Miossec L., Gozlan R.E. 2011. Non-native aquatic animals introductions have driven disease emergence in Europe. Biological Invasions 13 (6): 1291-1303.

DOI: $10.1007 /$ s10530-010-9890-9

Petrescu-Mag I.V., Lozinsky R.L., Csép L., Petrescu-Mag R.M. 2008. Vegetation and predators mediate color pattern frequencies in Poecilia sphenops Valenciennes. AACL Bioflux 1 (1): 51-61.

R Development Core Team 2014. A Language and Environment for Statistical Computing R Foundation for Statistical Computing, Vienna, Austria.

Raghavan R., Dahanukar N., Tlusty M.F., Rhyne A.L., Krishna Kumar K., Molur S., Rosser A.M. 2013. Uncovering an obscure trade: Threatened freshwater fishes and the aquarium pet markets. Biological Conservation 164: 158-169.

DOI: $10.1016 /$ j.biocon.2013.04.019

Rani P., Immanuel S., Kumar N.R. 2014. Ornamental fish exports from India: Performance, competitiveness and determinants. International Journal of Fisheries and Aquatic Studies 1 (4): 82-95.

Rhyne A.L., Tlusty M.F., Schofield P.J., Kaufman L., Morris J.A.jr., Bruckner A.W. 2012. Revealing the appetite of the marine aquarium fish trade: The volume and biodiversity of fish imported into the United States. PLoS One 7 (5): e35808.

DOI: 10.1371 journal.pone.0035808 
Ribeiro F., Elvira B., Collares-Pereira M.J., Moyle P.B. 2008. Life-history traits of non-native fishes in Iberian watersheds across several invasion stages: A first approach. Biological Invasions 10 (1): 89-102.

DOI: $10.1007 / \mathrm{s} 10530-007-9112-2$

Rixon C.A.M., Duggan I.C., Bergeron N.M.N., Ricciardi A., Macisaac H.J. 2005. Invasion risks posed by the aquarium trade and live fish markets on the Laurentian Great Lakes. Biodiversity and Conservation 14 (6): 1365-1381.

DOI: $10.1007 / \mathrm{s} 10531-004-9663-9$

Rylková K., Kalous L., Šlechtová V., Bohlen J. 2010. Many branches, one root: First evidence for a monophyly of the morphologically highly diverse goldfish (Carassius auratus). Aquaculture 302 (1-2): 36-41. DOI: 10.1016/j.aquaculture.2010.02.003

Simonović P., Tošić A., Vassilev M., Apostolou A., Mrdak D., Ristovska M., Kostov V., Nikolić V., Škraba D., Vilizzi L., Copp G.H. 2013. Risk assessment of non-native fishes in the Balkans Region using FISK, the invasiveness screening tool for non-native freshwater fishes. Mediterranean Marine Science 14 (2): 369-376.

DOI: $10.12681 / \mathrm{mms} .337$

Sobecka E., Luczak E., Marcinkiewicz M. 2012. New cases of pathogens imported with ornamental fish. Biological Letters 49 (1): 3-10.

DOI: $10.2478 / v 10120-012-0001-8$

Takada M., Tachihara K., Kon T., Yamamoto G., Iguchi K., Miya M., Nishida M. 2010. Biogeography and evolution of the Carassius auratus-complex in East Asia. BMC Evolutionary Biology 10, 7.

DOI: $10.1186 / 1471-2148-10-7$

Tlusty M. 2002. The benefits and risks of aquacultural production for the aquarium trade. Aquaculture $\mathbf{2 0 5}$ (3-4): 203-219.

DOI: $10.1016 / \mathrm{S} 0044-8486(01) 00683-4$
Tojo K., Tanaka Y., Kuranishi R.B., Kanada S. 2010. Reproductive biology and adaptability of the invasive alien freshwater amphipod Crangonyx floridanus (Crustacea: Amphipoda, Crangonyctidae). Zoological Science 27 (6): 522-527. DOI: $10.2108 / \mathrm{zsj} .27 .522$

van der Veer G., Nentwig W. 2014. Environmental and economic impact assessment of alien and invasive fish species in Europe using the generic impact scoring system. Ecology of Freshwater Fish 24 (4): 646-656. DOI: $10.1111 /$ eff.12181

Vesely T., Cinkova K., Reschova S., Gobbo F., Ariel E., Vicenova M., Pokorova D., Kulich P., Bovo G. 2011. Investigation of ornamental fish entering the EU for the presence of ranaviruses. Journal of Fish Diseases 34 (2): 159-166.

DOI: $10.1111 /$ j.1365-2761.2010.01224.x

Wang S.-Y., Luo J., Murphy R.W., Wu S.-F., Zhu C.-L., Gao Y., Zhang Y.-P. 2013. Origin of Chinese goldfish and sequential loss of genetic diversity accompanies new breeds. PLoS ONE 8 (3): e59571.

DOI: 10.1371 /journal.pone.0059571

Weir M., Rajić A., Dutil L., Uhland C., Bruneau N. 2012. Zoonotic bacteria and antimicrobial resistance in aquaculture: Opportunities for surveillance in Canada. Canadian Veterinary Journal 53 (6): 619-622.

Zięba G., Copp G.H., Davies G.D., Stebbing P., Wesley K.J., Britton J.R. 2010. Recent releases and dispersal of non-native fishes in England and Wales, with emphasis on sunbleak Leucaspius delineatus (Heckel, 1843). Aquatic Invasions 5 (2): 155-161.

DOI: 10.3391/ai.2010.5.2.04

Received: 7 April 2015

Accepted: 21 June 2014

Published electronically: 30 September 2015 